\title{
Accounting
}

\section{Business barriers and degree of internationalization of manufacturing companies in Peru}

\author{
Phan Anh Tu ${ }^{a^{*}}$ and Tran Phuong Thanha
}

${ }^{a}$ School of Economics, Can Tho University, Vietnam

\begin{tabular}{l}
\hline C H R O N I C L E \\
\hline Article history: \\
Received July 22020 \\
Received in revised format July \\
262020 \\
Accepted July 292020 \\
Available online \\
August 2 2020 \\
\hline Keywords: \\
Internationalization \\
Business barriers \\
Bribery cost \\
Peru
\end{tabular}

\section{A B S T R A C T}

This paper investigates the relationship between business barriers and the degree of internationalization of manufacturing enterprises in Peru. Using a panel data survey of 869 companies over the year 2006, 2010 and 2017, with Tobit regression model, the empirical results show that competition and transportation have negative impacts on internationalization process, whilst factors like international certification, tax administration, custom clearance and bribery cost have positive impacts. In addition, the factors that belong to individual managers affecting the internationalization of firms are not statistically significant. The study will give policy makers more information to support Vietnamese businesses in the process of internationalization.

\section{Introduction}

Internationalization is becoming a trend and goal to be achieved by the nation as well as businesses worldwide. In the $1960 \mathrm{~s}$, 7,000 multinational corporations were operating around the world while this number rose to 61,000 by the beginning of the century, with hundreds of thousands of employees working across borders (Scholte, 2005). This rapid increase is due to internationalization which is considered as an essential aspect in maximizing business opportunities, helping businesses access to many different markets, new customers, new suppliers, new technology and new collaboration capabilities. Favorable conditions will optimize the price and quality of the product, boosting the flow of goods sold, thereby affecting the survival and efficiency of business operations (Zahra \& George, 2002). Participating in Internationalization creates opportunities for businesses to develop their competitive advantages, thereby improving business value. In today's harsh competitive market, the decision to join Internationalization also becomes an essential condition for businesses, especially small and medium enterprises (SMEs). Peru is a potential economy with significant contributions from SMEs, but these businesses are vulnerable to trade barriers due to limited resources, ability, and risk-absorbing threshold low risk (Etemad, 2004; Goh \& Olivier, 2002). Therefore, it is necessary to study barriers and find ways to overcome them, not only for SMEs but also for all businesses in Peru's manufacturing industry.

\footnotetext{
* Corresponding author.

E-mail address: patu@ctu.edu.vn (P. A. Tu) 


\section{Literature review and hypotheses}

\subsection{Theoretical foundations and research hypotheses}

The theory of "Process of Internationalization" or "Uppsala model" was studied by Johanson and Vahlne (1977). The basic structure of this model is the distinction between the state aspect and the changing aspect of the factors in the process of Internationalization. Status aspects include market constraints (resource constraints on foreign markets) and knowledge of international markets. The changing aspect includes binding decisions and current activities. Decisions made based on existing experience and activities will help businesses gain those experiences and grow into knowledge. From there, companies can identify opportunities and risks to lead to binding decisions. Later, theories of Internationalization were developed and expanded by economists such as Johanson's network theory and Mattsson (1988) on market expansion and cooperation; the method of human resources developed by Wernerfelt (1984) and Barney (1991) to focus on the aspect of human resources; Dunning's eclectic theory (1988) refers to three advantages of firms: ownership, location advantage, and localization advantage. However, the implementation of internationalization, including export activities, is not always easy since there are still barriers set up to protect enterprises of importing countries. Most of the barrier studies are based on the Leonidou barrier theory (2004) which is developed according to the specific goals of the research, but basically, the barriers are either from within the enterprise or the external factors impact. This article focuses on the study of external barriers and the business environment of enterprises participating in Internationalization. Six main factors are being focused on research, including International certification (CER), the level of competition (COMP), tax administration (TAX_AD), transportation (TRANS), customs (CUS), and bribery (BRI). From that form, the research hypotheses of the topic as follows:

Hypothesis $\boldsymbol{H}_{1}$ : International certification is a business barrier that has a positive relationship with the degree of internationalization.

Hypothesis $\boldsymbol{H}_{2}$ : The degree of competition is a business barrier with an inverse relationship with the degree of internationalization.

Hypothesis $\boldsymbol{H}_{3}:$ Tax administration is a business barrier that is negatively related to the degree of internationalization.

Hypothesis $\boldsymbol{H}_{4}$ : The transport process is a business barrier that is negatively related to the degree of internationalization.

Hypothesis Hs: Customs and commercial law are business barriers that are inversely related to the degree of internationalization.

Hypothesis $\boldsymbol{H}_{6}:$ Bribery is a business barrier that is positively related to the degree of internationalization.

\subsection{Data and measurement}

The study uses secondary data sources surveyed by the World Bank and provides information collected in Peru, as part of the Latin American and Caribbean Business Survey (LAC). The dataset is the result of a survey of Peru's businesses in 2006, 2010, 2017, the data presented in tabular data includes firms in the three manufacturing sectors, retail services, and other services. The paper uses a part of the data set with a sample size of 1,068 observations of 869 manufacturing enterprises. Out of 869 businesses surveyed, 447 enterprises participated in Internationalization activities.

In order to consider the relationship between internal business barriers and the degree of internationalization implementation of manufacturing enterprises in Peru, the study uses the Tobit regression method to analyze with the estimation equation as follows,

$D O I=\beta_{0}+\beta_{1} C E R+\beta_{2} C O M P+\beta_{3} T A X_{A D}+\beta_{4} T R A N S+\beta_{5} C U S+\beta_{6} B R I+\beta_{7} F I R M S I Z E+\beta_{8} O P E R Y E A R+u i$

In which: $\beta_{0}$ is the primary factor; $\beta_{1}-\beta_{11}$ is the estimated coefficient of the model; $\mathrm{u}_{\mathrm{i}}$ is the error of the model.

The degree of internationalization (DOI) is calculated as the ratio of export sales (direct and indirect exports) to total revenue (Lu and Beamish, 2001) as shown in the following formula:

Degree of Internationalization $(\mathrm{DOI})=\frac{\text { Totalexportsales }}{\text { Totalrevenue }}$

International certification (CER) is a dummy variable, receiving value one if the enterprise gets any international quality certification (ISO 9000, 9002 or 14000), otherwise it gets a value of 0 (Botello, 2014) 
Competition level (COMP) is measured by managers answering questions on a Likert-5 scale ( 0 : No obstruction -> 4: Extremely obstructing).

Tax administration $\left(\boldsymbol{T A} \boldsymbol{X}_{\boldsymbol{A}}\right)$ is measured by managers answering questions on a Likert-5 scale (0: No obstruction $\rightarrow$ 4: Extremely obstructing).

Transport (TRANS) is measured by managers answering questions on a Likert-5 scale (0: No obstruction -> 4: Extremely obstructing).

Customs and trade rules (CUS) are measured by managers answering questions on a Likert-5 scale (0: No obstruction $\rightarrow>4$ : Extremely obstructing).

Bribery (BRI) is a payment of money to promote an action that is against the public interest or in violation of the law. That may be the fee for licensing procedures, licenses, customs, taxes, etc. BRI is measured by the ratio of the amount of lubrication that businesses have to spend on average in 2006, 2010, and 2017 divided by the total revenue of enterprises multiplied by 1,000 (multiplied by 1,000 to help this variable show the expected impact). From the above argument, the coefficient value of the BRI variable is positive and is calculated by the following formula:

Bribery $(\mathrm{BRI})=\frac{\text { Bribery }}{\text { TotalRevenue }} \times 1000$

Firm size (FIRMSIZE) is measured by taking the natural logarithm of the number of full-time employees at the business.

The number of years of operation of enterprises (OPERYEAR) is measured by the number of years of operation of the enterprise from its inception to the survey year 2006, 2010 and 2017.

Unskilled labor (UNSKILLED) is measured by the percentage of underemployed employees on the total number of employees in the enterprise.

Management experience (EXPER) is measured by the number of years of managerial experience as of the 2006, 2010 and 2017 surveys.

The gender of the manager (GENDER) is a dummy variable, receiving 1 if the manager is male and 0 if the manager is female. According to research by Felson and Gottfredson (1984), in many societies, men often have more conditions to interact outside society than women, while women are more closely monitored.

\section{Results and Discussion}

\subsection{Research result}

Table 1 presents the statistical results describing the variables to see an overview of data, including the number of observations, mean value, standard deviation, minimum value, maximum value, and value of in-force (VIF) shows the correlation coefficient of the variables in the research model.

\section{Table 1}

The results of basic statistics

\begin{tabular}{|c|c|c|c|c|c|c|}
\hline Variables & $\begin{array}{r}\text { Number of } \\
\text { observations }\end{array}$ & Mean & $\begin{array}{l}\text { Standard } \\
\text { deviation }\end{array}$ & Minimum & Maximum & VIF \\
\hline \multicolumn{7}{|l|}{ Dependent variables: } \\
\hline Degree of Internationalization (DOI) & 1.068 & 22.04 & 34.20 & 0 & 100 & \\
\hline \multicolumn{7}{|l|}{ Independent variables: } \\
\hline International certification (CER) & 1.068 & 0.31 & 0.46 & 0 & 1 & 1.30 \\
\hline Competition (COMP) & 1.068 & 2.19 & 1.25 & 0 & 4 & 1.12 \\
\hline Tax administration (TAX-AD) & 1.068 & 1.88 & 1.15 & 0 & 4 & 1.13 \\
\hline Transportation (TRANS) & 1.068 & 1.47 & 1.18 & 0 & 4 & 1.21 \\
\hline Customs (CUS) & 1.068 & 1.13 & 1.10 & 0 & 4 & 1.30 \\
\hline Bribery (BRI) & 1.068 & 782.77 & 2687.33 & 0 & 40.000 & 1.03 \\
\hline \multicolumn{7}{|l|}{ Control variables: } \\
\hline Firm size (FIRMSIZE) & 1.068 & 3.94 & 1.54 & 0.69 & 8.99 & 1.53 \\
\hline Operation years(OPERYEAR) & 1.068 & 24.17 & 18.68 & 1 & 119 & 1.22 \\
\hline Unskilled labor (UNSKILLED) & 1.068 & 0.24 & 0.24 & 0 & 0.93 & 1.07 \\
\hline Management experience (EXPER) & 1.068 & 23.16 & 11.44 & 1 & 65 & 1.06 \\
\hline Manager gender (GENDER) & 1.068 & 0.37 & 0.48 & 0 & 1 & 1.05 \\
\hline
\end{tabular}

Source: World Bank Enterprises Survey (2019) 
The degree of Internationalization in Peru is relatively low, reaching an average value of $22.04 \%$. The international certification variable (CER) has an average of 0.31 , indicating that the number of enterprises with international certification is not much. The competition (COMP), tax administration (TAXAD), transportation (TRANS), and customs (CUS) variables have average values in the range of 1 to 3, suggesting that these variables are mostly Enterprises assess that it is a low and moderate obstacle to their operations. The variable of the cost of lubrication with the lowest value is 0.000 The highest is 40,000 corresponding to the business without or having made informal expenses in the business process; the average value is 782.77, which shows that corruption in Peru is not prevalent. The average size of businesses reached 3.94 with the lowest value of 0.69 , and the highest was 8.99, so in Peru, mainly small and medium enterprises. The lowest year of business operation is one year, and the most extended service is 119 years; the average value is 24.17 . The variable of unskilled labor ranges from $0 \%$ to $0.93 \%$ and has an average rate of $0.24 \%$; with this rate, the unskilled labor in Peru is also quite high. The managerial experience ranges from 1 year to 65 years; the average value is 23.16; the managers in Peru are mostly senior, experienced people. The manager's gender is a dummy variable with one being female, 0 being male, the average is 0.37 , the number of managers in Peru is mostly male.

Table 2

Correlation matrix (bivariate Pearson)

\begin{tabular}{|c|c|c|c|c|c|c|c|c|c|c|c|c|c|c|}
\hline Variables & Mean & $\begin{array}{l}\text { Standard } \\
\text { deviation }\end{array}$ & (1) & (2) & (3) & (4) & (5) & (6) & (7) & (8) & (9) & (10) & (11) & (12) \\
\hline 1. DOI & 22,04 & 34,20 & 1.000 & & & & & & & & & & & \\
\hline 2. FIRMSIZE & 3,94 & 1,54 & $0,255^{* * *}$ & 1.000 & & & & & & & & & & \\
\hline 3. OPERYEAR & 24,17 & 18,68 & $-0,101^{* * *}$ & $0,321^{* * *}$ & 1.000 & & & & & & & & & \\
\hline 4.UNSKILLED & 0,24 & 0,24 & $0,095^{* * *}$ & $0,195^{* * *}$ & $-0,026$ & 1.000 & & & & & & & & \\
\hline 5.EXPER & 23,16 & 11,44 & $-0,050^{*}$ & $-0,029$ & $0,198^{* * *}$ & 0,003 & 1.000 & & & & & & & \\
\hline 6.GENDER & 0,37 & 0,48 & $-0,063^{* * *}$ & $0,125^{* * *}$ & $-0,073^{* *}$ & $-0,090^{* * *}$ & $0,052^{*}$ & 1.000 & & & & & & \\
\hline 7. CER & 0,31 & 0,46 & $0,167^{* * *}$ & $0,454^{* * *}$ & $0,236^{* * *}$ & 0,006 & $-0,027$ & $-0,121^{* * *}$ & 1.000 & & & & & \\
\hline 8. СOMP & 2,19 & 1,25 & $-0,138^{* * *}$ & $-0,186^{* * *}$ & $-0,016$ & $-0,031$ & 0,037 & $0,094^{* * *}$ & $-0,114^{* * *}$ & 1.000 & & & & \\
\hline 9. TAX_AD & 1,88 & 1,15 & 0,050 & 0,002 & 0,047 & 0.021 & $-0,010$ & 0,039 & $-0,012$ & $0,208^{* * *}$ & 1.000 & & & \\
\hline 10. TRANS & 1,47 & 1,18 & $-0,053^{*}$ & $-0,011$ & 0,029 & 0,011 & $-0,006$ & 0,030 & 0,008 & $0,156^{* * *}$ & $0,209^{* * *}$ & 1.000 & & \\
\hline 11. CUS & 1,13 & 1,10 & $0,102^{* * *}$ & $0,190^{* * *}$ & $0,054^{*}$ & 0,012 & 0,029 & $-0,025$ & $-0,135^{* * *}$ & $0,136^{* * *}$ & $0,257^{* * *}$ & $0,384^{* * *}$ & 1.000 & \\
\hline 12. BRI & 782,77 & 2687,33 & $0,099^{* * * *}$ & $-0,120^{* *}$ & $-0,089^{* * *}$ & $-0,047$ & $-0,027$ & 0,012 & $0,085^{* * *}$ & 0.023 & $0,076^{* *}$ & 0.013 & -0.029 & 1.000 \\
\hline
\end{tabular}

Source: World Bank Enterprises Survey (2019)

Note: $(*)$ : significance level of $10 \% ;(* *)$ : significance level of $5 \% ;(* * *)$ : significance level $1 \%$

Table 3

Results of Tobit regression analysis

\begin{tabular}{|c|c|c|c|c|c|c|c|c|}
\hline $\begin{array}{l}\text { Variable names } \\
\text { Independent variables }\end{array}$ & Model (1) & Model (2) & Model (3) & Model (4) & Model (5) & Model (6) & Model (7) & $\mathrm{dy} / \mathrm{dx}$ \\
\hline CER & & $\begin{array}{l}13,056^{*} \\
(3,150)\end{array}$ & $\begin{array}{l}12,707^{*} \\
(3,080)\end{array}$ & $\begin{array}{l}12,402^{*} \\
(3,000)\end{array}$ & $\begin{array}{l}12,460^{*} \\
(3,020)\end{array}$ & $\begin{array}{l}11,510^{*} \\
(2,770)\end{array}$ & $\begin{array}{l}11,836^{*} \\
(2,900)\end{array}$ & 5,931 \\
\hline COMP & & & $\begin{array}{c}-2,536 \\
(-1,660)\end{array}$ & $\begin{array}{l}-3,531^{*} \\
(-2,270)\end{array}$ & $\begin{array}{c}-3,382^{*} \\
(-2,180)\end{array}$ & $\begin{array}{c}-4,037^{*} \\
(-2,590)\end{array}$ & $\begin{array}{l}-3,957^{*} \\
(-2,560)\end{array}$ & $-1,983$ \\
\hline TAX-AD & & & & $\begin{array}{l}5,468^{*} \\
(3,470)\end{array}$ & $\begin{array}{l}5,702^{*} \\
(3,560)\end{array}$ & $\begin{array}{l}4,459^{*} \\
(2,710)\end{array}$ & $\begin{array}{c}4,005^{*} \\
(2,46)\end{array}$ & 2,007 \\
\hline TRANS & & & & & $\begin{array}{c}-1,293^{n \cdot s} \\
(-0,860)\end{array}$ & $\begin{array}{l}-3,754^{*} \\
(-2,270)\end{array}$ & $\begin{array}{l}-3,738^{*} \\
(-2,280)\end{array}$ & $-1,873$ \\
\hline CUS & & & & & & $\begin{array}{l}7,342^{*} \\
(4,060)\end{array}$ & $\begin{array}{l}7,439^{*} \\
(4,120)\end{array}$ & 3,728 \\
\hline BRI & & & & & & & $\begin{array}{l}0,002^{*} \\
(2.420)\end{array}$ & 0,001 \\
\hline \multicolumn{9}{|l|}{ Control variables } \\
\hline FIRMSIZE & $\begin{array}{l}14,841^{*} \\
(12,360)\end{array}$ & $\begin{array}{l}13,159^{*} \\
(10,080)\end{array}$ & $\begin{array}{c}12,751^{*} \\
(9,670)\end{array}$ & $\begin{array}{c}12,772^{*} \\
(9,640)\end{array}$ & $\begin{array}{c}12,738^{*} \\
(9,620)\end{array}$ & $\begin{array}{l}11,791^{*} \\
(8,760)\end{array}$ & $\begin{array}{l}12,008^{*} \\
(9,000)\end{array}$ & 6,017 \\
\hline OPERYEAR & $\begin{array}{l}-0,501^{*} \\
(-5,730)\end{array}$ & $\begin{array}{l}-0,540^{*} \\
\quad(-6,080)\end{array}$ & $\begin{array}{l}-0,531^{*} \\
(-5,980)\end{array}$ & $\begin{array}{l}-0,550^{*} \\
(-6,270)\end{array}$ & $\begin{array}{r}-0,546^{*} \\
(-6,250)\end{array}$ & $\begin{array}{r}-0,527^{*} \\
(-6,000)\end{array}$ & $\begin{array}{r}-0,507^{*} \\
(-5,820)\end{array}$ & $-0,254$ \\
\hline UNSKILLED & $\begin{array}{r}11,037^{n . s} \\
(1,440)\end{array}$ & $\begin{array}{l}13,189 \\
(1,730)\end{array}$ & $\begin{array}{l}13,358 \\
(1,750)\end{array}$ & $\begin{array}{r}12.675 \\
(1,670)\end{array}$ & $\begin{array}{r}12,783 \\
(1,690)\end{array}$ & $\begin{array}{l}14,333 \\
(1,900)\end{array}$ & $\begin{array}{l}15,199^{*} \\
(2,040)\end{array}$ & 7,616 \\
\hline EXPER & $\begin{array}{r}0,022^{n . s} \\
(0,150)\end{array}$ & $\begin{array}{l}0,040^{n . s} \\
\quad(0,280)\end{array}$ & $\begin{array}{l}0,047^{n . s} \\
\quad(0,330)\end{array}$ & $\begin{array}{l}0,058^{n . s} \\
\quad(0,400)\end{array}$ & $\begin{array}{l}0,057^{n . s} \\
\quad(0,400)\end{array}$ & $\begin{array}{l}0,024^{n . s} \\
(0,170)\end{array}$ & $\begin{array}{l}0,028^{\text {n.s }} \\
(0,190)\end{array}$ & 0,014 \\
\hline GENDER & $\begin{array}{r}-0,277^{n . s} \\
(-0,070)\end{array}$ & $\begin{array}{l}0,798^{n . s} \\
\quad(0,210)\end{array}$ & $\begin{array}{l}1,224^{\text {n.s }} \\
(0,330)\end{array}$ & $\begin{array}{l}0,598^{\text {n.s }} \\
\quad(0,160)\end{array}$ & $\begin{array}{l}0,604^{\text {n.s }} \\
\quad(0,160)\end{array}$ & $\begin{array}{l}1,014^{\text {n.s }} \\
\quad(0,270)\end{array}$ & $\begin{array}{r}1,082^{\text {n.s }} \\
(0,290)\end{array}$ & 0,542 \\
\hline Constant & $\begin{array}{l}-49,282 \\
(-7,410)\end{array}$ & $\begin{array}{l}-20,992 \\
(-1,880)\end{array}$ & $\begin{array}{l}-14,911 \\
(-1,270)\end{array}$ & $\begin{array}{l}-23,099 \\
(-1,910)\end{array}$ & $\begin{array}{l}-21,793 \\
(-1,790)\end{array}$ & $\begin{array}{l}-21,045 \\
(-1,730)\end{array}$ & $\begin{array}{l}-23,116 \\
(-1,920)\end{array}$ & \\
\hline Log Likelihood & $-3308,146$ & $-3303,355$ & $-3301,829$ & $-3295,980$ & $-3295,626$ & $-3287,622$ & $-3282,53$ & \\
\hline $\begin{array}{l}\text { Prob }>\mathrm{F} \\
\text { Pseudo value } R^{2}\end{array}$ & $\begin{array}{r}0,000 \\
0.0909\end{array}$ & $\begin{array}{r}0,000 \\
0.1043\end{array}$ & $\begin{array}{r}0,000 \\
0.1147\end{array}$ & $\begin{array}{r}0,000 \\
0.1264\end{array}$ & $\begin{array}{r}0,000 \\
0.1266\end{array}$ & $\begin{array}{r}0,000 \\
0.1289\end{array}$ & $\begin{array}{r}0,000 \\
0.1304\end{array}$ & \\
\hline Number of observations & 1.068 & 1.068 & 1.068 & 1.068 & 1.068 & 1.068 & 1.068 & \\
\hline
\end{tabular}

Test the multicollinearity phenomenon of variables in the model by using the variance magnification factor (VIF) to determine 
the correlation between variables. Typically, when VIF $>10$, the variable is considered to have high multicollinearity, while VIF $>2$, that variable may appear to have a multi-collinear phenomenon. Examining VIF results $<2$ of the research model concludes that no multi-collinear miracles occurred. The correlation matrix in Table 2 shows the correlation of the independent variables with dependent variables (most independent variables have significance levels below 5\%). Besides, the correlation coefficient (r) of the independent variables in the model is lower than the value of 0.8 , so it can be concluded that the model is not multi-collinear. The results of the regression model with the value Prob $>F=0.000$ represent the $F$ test's significance level of less than 5\%, proving the model's suitability. Combined with estimating the maximum likelihood that is calculated and used to create confidence levels, the likelihood can be used to test hypotheses about models and parameters. The result of the loglikelihood value obtained is 3282.53, which is large enough to conclude that the research model's reliability is high. The coefficient of determination of model $\mathrm{R}^{2}=0.1304=13.04 \%$ means six international certification variables, competition level, tax administration, transportation, customs, and bribery are explained 13, 04\% of the fluctuation of the variable depends on the degree of internationalization of manufacturing enterprises in Peru. Moreover, the primary independent variables mostly have significant levels of $1 \%, 5 \%$ and $10 \%$, from which can conclude that the research model is meaningful and reliable.

\subsection{Results and discussion}

To measure the probability of the independent variable affecting the dependent variable, the author has calculated the marginal effect value obtained by the $\mathrm{dy} / \mathrm{dx}$ result presented in Table 3 with the results of model 7 (the most variable full model).

International certification: there is a positive relationship with the level of internationalization at $1 \%$ significance level $(\beta=$ $11,836 ; \mathrm{p}<0.01)$. When keeping other factors fixed, owning more and more international certificates will reduce the barriers of enterprises' participation in Internationalization to promote enterprises to conduct Internationalization. In particular, difficulties will reduce 5,931 applications, when businesses have extensive access to foreign markets. To obtain international certification such as ISO 9000, 14000, etc., enterprises must make efforts to complete common standards (Chen et al., 2008). Having a certificate helps businesses easily penetrate and export their goods to countries around the world. Moreover, increasing added value for products, meeting the requirements of importers, reinforcing consumer confidence.

Competition level: there is an inverse relationship with the level of internationalization at the $5 \%$ significance level $(\beta=11,836$; $\mathrm{p}<0,01)$. Other factors are constant, the level of competition with the informal sector increases by 1 unit, and the level of participation in Internationalization of enterprises decreases by 1,983 units. This result shows that when formal and informal enterprises in the country compete fiercely with each other, participation in Internationalization is rarely considered because enterprises have to focus on accumulating knowledge and resources to compete in the domestic market (Zeng et al., 2008) and also because enterprises do not have enough potential to compete with domestic enterprises in the world market.

Tax administration: there is a positive relationship with the degree of Internationalization at a significant level of 5\% $(\beta=-$ $3,957 ; \mathrm{p}<0,05)$. When other factors are fixed, the tighter the tax administration, the participation in internationalization increases by 2,007 units. Thus, the results obtained are meaningful but contrary to expectations. The Peruvian government has issued a new tax policy, clear regulations on tax collection, and simplification of tax codes. The establishment of the National Tax Administration (SUNAT) is an administrative and financial autonomy agency that creates community support. The State encourages domestic exports to apply $0 \%$ tax rate to all goods and enterprises participating in Internationalization, which are supported by the State.

Transportation problems: there is an inverse relationship with the degree of internationalization $(\beta=-3,738$; $p<0,05)$. This means that when other factors are constant, cargo transportation increases and the level of participation in enterprises' internationalization decreases by 1,873 units. When participating in internationalization, the movement of goods, supplies, and input materials become more diverse and easier through cooperation with countries in the region, in the world, and through imports. Transport difficulties are affected by factors such as transportation costs, transport infrastructure, and logistics networks that increase costs when transporting goods, supplies, and input materials for businesses to be reluctant to join internationalization, especially for SMEs. Peru is investing heavily in the development of transport systems (roads, aviation, trains, etc.) infrastructure and equipment to facilitate the import and export of goods.

Customs and trade rules: have a positive relationship with the level of internationalization at $1 \%$ significance level $(\beta=7,439$; $p<0,01)$. This means that when other factors are fixed, customs obstacles and trade rules increase, the degree of internationalization increases by 3,728 units. Thus, the results obtained are meaningful but contrary to expectations. In fact, according to a survey of enterprises in 2006, 2010, and 2017 on the selection of 10 barriers to the business activities of manufacturing enterprises in Peru, customs and commercial law were not considered a concern of the business. It proves that the SUNAT autonomous tax management system has worked effectively in Peru.

Bribery: has a positive relationship with the degree of internationalization at a significant level of $5 \%(\beta=0.002 ; \mathrm{p}<0.05)$. When other factors are constant, the cost of bribery increases by $1 \%$, the participation rate of enterprises' internationalization increases but very little, approximately 0.001 units. Bribery helps businesses achieve economic benefits because the waiting time is shortened; businesses do not have to trade high opportunity costs. 


\section{Conclusion and policy implications}

The empirical research results confirm the business environment barriers that have significant impacts on the degree of internationalization include: International certification, the level of competition and transportation were inversely related to the degree of internationalization; Tax administration, customs issues, and bribery costs were positively related to the level of administrative procedure. Regarding the control variable in the model, the larger the size of the enterprise, the higher the level of regulatory reform, the longer the number of years of operation of the enterprise, the restriction of the process of administrative change, the lack of qualification of the labor force increases when the administrative cost increases. Some of the research implications are drawn from the analytical results as follows:

Firstly, businesses need to focus on building appropriate strategies to penetrate the international market in each period. Specifically, in the first phase, the company's business results are significantly improved, but the benefits that companies gain after penetration will gradually decrease as the costs are incurred in the importing country (country investment reception) increasing. Therefore, to overcome the damage of long-term benefits, businesses need to formulate business strategies in the short, medium, and long term when participating in internationalization.

Secondly, export promotion policymakers should issue support and preferential policies for export enterprises (including foreign-invested enterprises) to help these enterprises be able to maintain business activities (market share) for a long time in the import market.

Thirdly, strengthening infrastructure development, including ports, airports, and logistics because Peru's infrastructure system is still flawed and degraded.

Fourthly, it is necessary to have measures to transform and encourage informal enterprises to move to operate in Peru officially. The informal enterprises account for $30-40 \%$ of the total manufacturing enterprises, mainly working in the form of households, small and medium scale, operating in the domestic market.

Fifthly, the Government should pay attention to investing in education, creating favorable conditions for Peruvian people to access quality, reasonably priced education services at the university level and technical vocational training, thereby raising their qualifications. Such as skills of workers participating in the production, creating an advantage when conducting internationalization.

\section{References}

Barney, J. (1991). Firm resources and sustained competitive advantage. Journal of Management, 17(1), 99-120.

Botello, H. A. (2014). Condiciones y determinantes de la internacionalización de las empresas industriales latinoamericanas. Apuntes. Revista de ciencias sociales, 41(75), 47-78.

Dunning, J. H. (1988). The eclectic paradigm of international production: A restatement and some possible extensions. Journal of International Business Studies, 19(1), 1-31.

Etemad, H. (2004). Internationalization of small and medium sized enterprises: A grounded theoretical framework and an overview. Canadian Journal of Administrative Sciences, 21(1), 1-21.

Felson, M. \& Gottfredson, M., (1984). Social indicators of adolescent activities near peers and parents. Journal of Marriage and Family, 43(6), 709.

Goh, A.T. \& Olivier, J. (2002). Optimal patent protection in a two-sector economy. International Economic Review, 43(4), 1191-1214

Johanson, J., \& Mattsson, L.-G. (1988), Internationalization in industrial systemsinternationalization - a network approach in Hood, N. and Vahlne, J.-E. (Eds), Strategies in Global Competition, John Wiley, Chichester and New York, NY, pp. 287-314.

Johanson, J. \& Vahlne, J. E. (1977). The internationalization process of the firm - A model of knowledge development and increasing foreign market commitments. Journal of International Business Studies, 8(1), 23-32

Leonidou, L. C. (2004). An analysis of the barriers hindering small business export development. Journal of Small Business Management, 42(3), 279-302.

Lu, J. W. \& Beamish, P. W. (2001). The internationalization and performance of SMEs. Strategic Management Journal, 22, 565-586.

Scholte, J. A. (2005), Globalization: a critical introduction, Macmillan International Higher Education, UK.

Wernerfelt, B. (1984). A resource-based view of the firm. Strategic Management Journal, 5, 171-180.

Zahra, S. A. \& George, G. (2002). Absorptive capacity: A review, reconceptualization, and extension. Academy of Management Review, 27(2), 185-203.

Zeng, S. X., Xie, X. M., Tam, C. M., Wan, T. W. (2008). Competitive priorities of manufacturing firms for internationalization: An empirical research. Measuring Business Excellence, 12(3), 44-55.

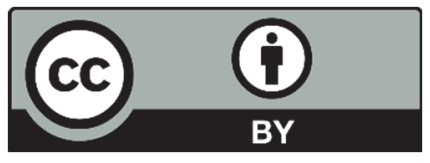

(C) 2020 by the authors; licensee Growing Science, Canada. This is an open access article distributed under the terms and conditions of the Creative Commons Attribution (CC-BY) license (http://creativecommons.org/licenses/by/4.0/). 